\title{
Checkered beetles moths (Lepidoptera: Gracillariidae) - hazardous phytophags of arboreal and shrubby plants of botanical gardens and plantings of Kiev
}

\author{
M. Lisovyi, \\ O. Sylchuk \\ Natsional University of Life and Environmental Sciences of Ukraine, Heroev \\ Oborony str., 13, Kyiv, 03041, Ukraine \\ P. Chumak, \\ V. Kovalchuk, \\ Botanichny Garden of Acad. O. Fomina
}

The purpose. To carry out probes on revealing and specification of species composition of checkered moths (Lepidoptera: Gracillariidae) in conditions of botanical gardens and plantings of Kiev. Methods. Standard methods of faunistic research in entomology, population ecology, and protection of plants. Results. It is determined that 24 kinds of checkered moths are eating 54 kinds of plants which are widely used for gardening in Kiev. For the first time the following kinds are revealed: Phyllonorycter issikii, Phyllonorycter platani, and Phyllonorycter emberizaepennella. At calculation of Palii-Kovnatski indexes they specified that in city plantings the dominant phytophags are Cameraria ohridella (94,11\%), Phyllonorycter populifoliella $(86,37 \%)$ and Gracillaria syringella $(59,14 \%)$. They consider that in formation of the secondary areal of invasion kinds of checkered moths the great value has an areal of spread of the host-plant. Environmental analysis is carried out of checkered moths of family Gracillariidae which is spread in cities of the Europe and which are absent in fauna of cities of Ukraine. That has important theoretical and practical value for ecology, entomology and protection of plants against hazardous checkered moths. Conclusions. All the probed kinds of checkered moths by their trophic specialization may be distributed into polyphages (6 kinds), oligophages (14 kinds) and monophages (3 kinds).

Key words: checkered moth, phytophage, arboreal woody plants, trophic circuit.

Among the complex of pests of woody plants in the botanical gardens and plantations cities Ukraine is common and harmful insects (60\% of the total), including the recently acquired mass reproduction gracillariidae (Gracillariidae). In Ukraine greenery found more than 20 kinds of moles, strokatok [1]. In recent years (2004 - 2016)

the number of species of this group increased by herbivores. This is mainly adventitious species: Lhyllonorycter platini Staudinger, 1870 [2,3], Phyllonorycter issikii Kumata, 1963 [4,5,6], Cameraria ohridella Deschka \& Dimic, $1986[7,8]$. It is known that adventitious species got a new territory favorable for their development and reproduction conditions for the availability of sufficient food resources, lack of natural enemies very quickly expanding area. So, to prevent mass distribution of these species should be carried out regularly monitored, with the aim of early detection of insect cells.

Objective: to clarify the species composition of insect herbivores minuyuchyh woody plants $\mathrm{m}$. Kyiv.

Materials and methods. The study was conducted (2010-2016 gg.) In botanical gardens and parks of the city. Kyiv. Monitoring and accounting for the appearance of damage (formation min) leaf fodder plants was performed $[9,8]$. To determine the density of settlement herbivores plants were at least 100 leaves. Henetaley specimens of moths produced in this way. Separated abdomen adult soaked in $10 \% \mathrm{KOH}$ for 24 hours or heated for 30 minutes, purified preparuvalnoyu needle eosin stained B (males) or hlorazolom black (female), put a drop of glycerol and examined under a microscope with an increase of 200's or 400 's. Identification moles, strokatok carried out by methods [10,11,12,13]. Also used a computerized version of «Global Taxonomic Database of Gracillariidae (Lepidoptera)». 
To characterize species-complex moles used strokatok occurrence index $(\mathrm{Pi})$ and the index of dominance. Index occurrence [14] - the ratio of the number of samples ( $\mathrm{nl})$, which was found gracillariidae (regardless of the number of individuals in the sample) to the total number of samples $(\mathrm{N}): \mathrm{Pi}=(\mathrm{nl} / \mathrm{N})$ $100 \%$. Index dominance Paly-Kovnatski - a measure of how much dominated by this type over the other identified species than the frequency of occurrence, and the number of animals in the outbreak: $\mathrm{Di}=\mathrm{pi} \mathrm{Ni}$ / Ns, where Pi - occurrence type, NI - number of individuals and - the first type, Ns - total number of individuals. Plants zhyvyteli-identified types of moles, strokatok are under the directory $[15,16,17]$.

Results and discussion. Studies have phytosanitary state tree plantations Botanical Garden to them. Acad. OV Fomin Botanical Garden to them. Grisha NAS of Ukraine and park and street plantations. Kyiv (2000 2016 years.) Showed that 54 kinds of forage plants were found 24 species of moles, strokatok (Table. 1).

1. Species composition strokatok-moles (Gracillariidae) and their forage plants

\begin{tabular}{|c|c|}
\hline Mill-lagurus & Feed plants \\
\hline Caloptilia semifascia (Haworth), 1828 & $\begin{array}{l}\text { Acer negundo L., Acer platanoides L., Acer } \\
\text { campestre (L.) }\end{array}$ \\
\hline Caloptilia rufipennella (Hübner), 1796 & Acer platanoides L., Acer saccharinum L. \\
\hline Cameraria ohridella Deshke \& Dimic, 1986 & Aesculus hippocastanum L. \\
\hline Gracillaria syringella (Fabricius), 1794 & $\begin{array}{l}\text { Syringa vulgaris L., Symphoricarpus albus (L.) Blake, } \\
\text { Euonymus sp., Fraxinus excelsior L., Ligustrum sp., } \\
\text { Forsythia sp., Jasminum fruticans L. }\end{array}$ \\
\hline Parectopa robiniella (Clemens), 1863 & $\begin{array}{l}\text { Robinia pseudoacacia L., } R . \quad \text { pseudoacacia L. } \\
\text { 'Pyramidalis', } R . \text { pseudoacacia } \\
\text { viscose Vent. }\end{array}$ \\
\hline Phyllocnistis labyrinthella (Bjerkander), 1790 & $\begin{array}{l}\text { Populus alba L., P. x berolinensis (K. Koch) Dipp., P. } \\
x \text { canescens (Ait.) Smith, P. italica (Du Rol) Moench, } \\
\text { P. nigra L., P. simonii Carr. }\end{array}$ \\
\hline Phyllonorycter acerifoliella (Zeller), 1839 & Acer saccharinum $\mathrm{L}$. \\
\hline Phyllonorycter agilella (Zeller), 1846 & Ulmus glabra Huds. \\
\hline Phyllonorycter apparella (Herrich-Schaffer), 1855 & Populus tremula L. \\
\hline Phyllonorycter blancardella Fabricius, 1781 & Malus Mill. \\
\hline $\begin{array}{l}\text { Phyllonorycter cerasicolella Herrich-Schaffer, } \\
1855\end{array}$ & Cerasus vugaris Mill. \\
\hline Phyllonorycter coryli Nicelli, 1851 & Coryllus avellana L. \\
\hline Phyllonorycter emberizaepennella Bouche, 1834 & $\begin{array}{l}\text { Lonicera tatarica L., Lonicera xylosteum L., } \\
\text { Symphoricarpos albus L. }\end{array}$ \\
\hline Phyllonorycter faginella (Zeller), 1846 & Fagus sylvatica L. \\
\hline Phyllonorycter guercifoliella (Zeller), 1839 & Quercus robur L. \\
\hline Phyllonorycter issikii (Kumata), 1963 & Tilia cordata Mill., T.platyphyllos Scop. \\
\hline Phyllonorycter platani (Staudinger), 1870 & Platanus orientalis L., P. $\mathrm{x}$ acerifolia (Ait.)Wild. \\
\hline Phyllonorycter populifoliella (Treitschke), 1833 & Populus italica (Du Roi) Moench, P.nigra L. \\
\hline Phyllonorycter strigulatella (Zeller), 1846 & $\begin{array}{l}\text { Alnus glutinosa (L.)Gaertn., Alnus incana (L.) } \\
\text { Moench }\end{array}$ \\
\hline Phyllonorycter salicicolella (Sircom), 1848 & Populus nigra L., Salix alba L. \\
\hline Phyllonorycter sorbi Frey, 1855 & $\begin{array}{l}\text { Sorbus aucuparia L., Cotoneaster Medik., Crataegus } \\
\text { L., Malus Mill., Padus Mill., Prunus L. }\end{array}$ \\
\hline Phyllonorycter tenerella (de Joannis), 1915 & Carpinus betulus L. \\
\hline Phyllonorycter ulmifoliella (Hübner), 1817 & Betula pendula Roth., Betula pubescens Ehrh. \\
\hline Phyllocnistis labyrinthella (Bjerkander), 1790 & Populus italica (Du Roi) Moench, P.nigra L., P.alba L. \\
\hline
\end{tabular}


The study found about 24 species of insect herbivores on their trophic specialization showed schopolifahamy are 6 types:

Gracillaria syringella, Phyllocnistis labyrinthella, Phyllonorycter emberizaepennella, Phyllonorycter salicicolella, Phyllonorycter sorbi, Phyllocnistis labyrinthella, olihofahamy (14 species)

- Caloptilia semifascia, Caloptilia rufipennella, Parectopa robiniella, Phyllonorycter acerifoliella, Phyllonorycter apparella, Phyllonorycter blancardella, Phyllonorycter cerasicolella, Phyllonorycter coryli, Phyllonorycter guercifoliella, Phyllonorycter issikii, Phyllonorycter populifoliella, Phyllonorycter strigulatella, Phyllonorycter tenerella, Phyllonorycter ulmifoliella і монофами є 3 види: Cameraria ohridella, Phyllonorycter faginella та Phyllonorycter platani.

For the first time in the area of research we found three types of moles, strokatok:

Phyllonorycter issikii, Phyllonorycter platani and

Phyllonorycter emberizaepennella (!!!).This suggests that Entomofauna Ukraine is constantly updated with new types of settlers that may have unintended consequences, such as chestnut minuyucha moth, western corn rootworm (diabrotyka), potato moth and others.

Analysis moth spread in different types of green cities showed that most species recorded in the botanical gardens ( 23 taxa) and parks - 16 species. In plants that grow in the alleys and along roads with heavy traffic only found six types of moles, strokatok (tab. 2).

2. Distribution-discovered species of moles strokatok by type spaces in Kyiv

\begin{tabular}{|l|l|l|l|}
\hline Kind & $\begin{array}{l}\text { Botanical } \\
\text { gardens }\end{array}$ & $\begin{array}{l}\text { Parks and } \\
\text { gardens }\end{array}$ & The Street \\
\hline Caloptilia semifascia & + & + & - \\
\hline Caloptilia rufipennella & + & + & - \\
\hline Cameraria ohridella & + & + & + \\
\hline Gracillaria syringella & + & + & - \\
\hline Parectopa robiniella & + & + & - \\
\hline Phyllocnistis labyrinthella & + & + & + \\
\hline Phyllonorycter acerifoliella & + & + & - \\
\hline Phyllonorycter agilella & + & + & - \\
\hline Phyllonorycter apparella & + & - & - \\
\hline Phyllonorycter blancardella & + & + & - \\
\hline Phyllonorycter cerasicolella & + & + & + \\
\hline Phyllonorycter coryli & + & - & - \\
\hline Phyllonorycter emberizaepennella & + & - & - \\
\hline Phyllonorycter faginella & + & - & - \\
\hline Phyllonorycter guercifoliella & + & - & - \\
\hline Phyllonorycter issikii & - & + & - \\
\hline Phyllonorycter platani & + & - & - \\
\hline Phyllonorycter populifoliella & + & + & + \\
\hline Phyllonorycter strigulatella & + & - & - \\
\hline Phyllonorycter salicicolella & + & + & - \\
\hline Phyllonorycter sorbi & + & - & - \\
\hline Phyllonorycter tenerella & + & + & - \\
\hline Phyllonorycter ulmifoliella & + & + & - \\
\hline Phyllocnistis labyrinthella & + & + & - \\
\hline & + & & - \\
\hline
\end{tabular}

Note: "+" - found; "-" - no view

Calculation of the index occurrence moles feed on plants in the city. Kiev showed that most plants are damaged C. ohridella (8,54\%) and P. populifoliella (5,16\%) (Fig. 1, 1a). 


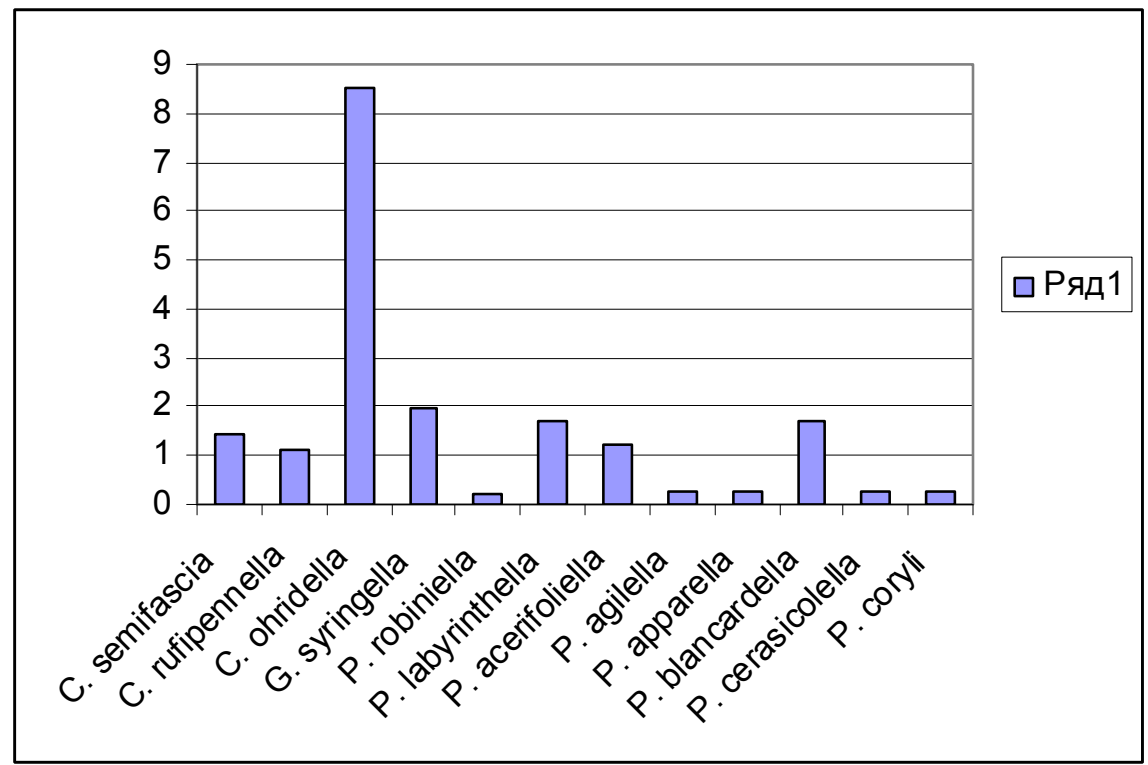

Fig. 1. Index-occurrence moles strokatok greenery in the city. Kyiv (2010-2016).

According to calculations conducted indices Paly-Kovnatski found that the city stands dominants are three types of moles, strokatok (C. ohridella $(94,11 \%)$, P. populifoliella $(86,37 \%)$ and Gracillaria syringella $(59,14 \%)$.

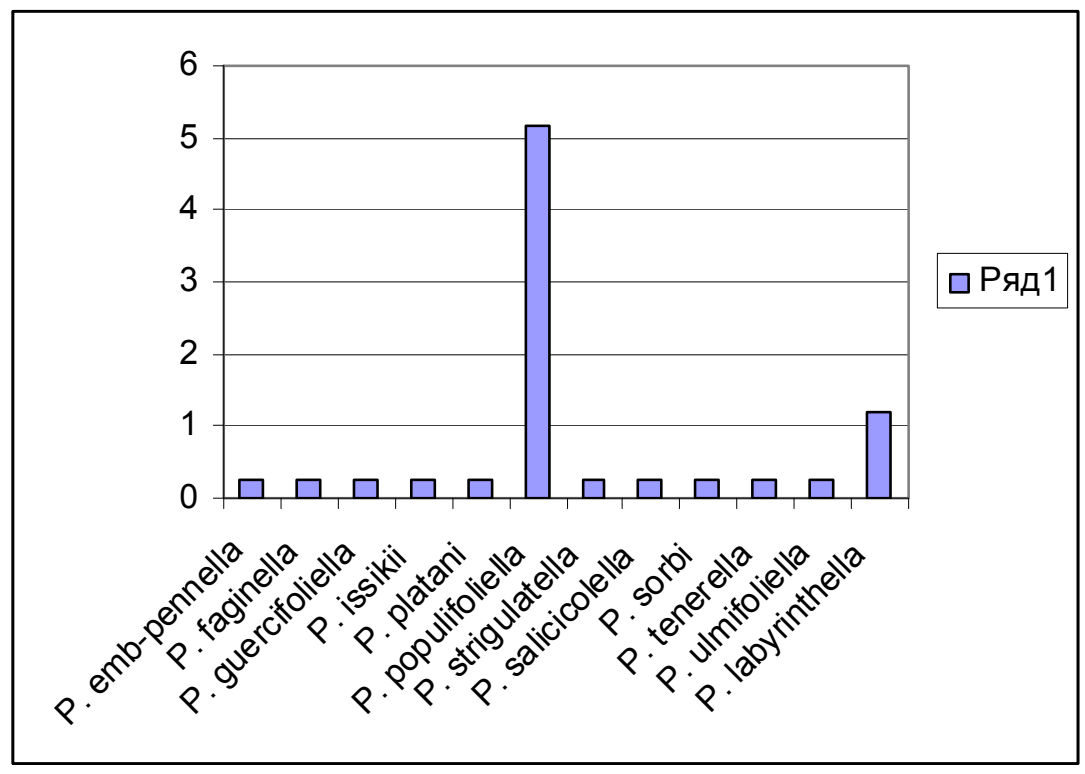

Fig. 1a. Continued Fig. 1: Index-occurrence moles strokatok greenery in the city. Kyiv (2010-2016).

We believe that the formation of secondary area moles, invasive species are important strokatok complex of climatic factors and range plant zhyvetelya. Thus, for example, expanding the range of Platanus orientalis L. and P. $x$ acerifolia (Ait.) Wild. contributed to the expansion of the range Phyllonorycter platani (Staudinger).

Comparing the results of studies on the spread of this group of insect herbivores in botanical gardens and urban green plantations in other cities of the former Soviet Union can note that they were fragmented. Thus, in $[18,19]$ are only two types of moles, strokatok

(Gracillaria syringella та Phyllonorycter populifoliella), which are common in Minsk. AA Rupays [20] fauna of Baltic Cities cites 14 types of moles, strokatok. In St. Petersburg on plants that grow in the city identified 11 types of moles, strokatok [21,22]. A study of these insects dendrophilous forests and parks of Armenia shows that among the identified herbivores happens only 9 types of moles, strokatok [23,24]. 
It should be noted that since these studies fauna in many cities of the former Soviet Union, there have been dramatic changes size and quantitative mass reproduction of alien species, strokatok moles. So rapid spread of mass reproduction and acquired in recent years gracillariidae -

Cameraria ohridella, Parectopa robiniella, Phyllonorycter issikii. From our analysis, the spread of alien moles strokatok in a park in Europe follows a logical conclusion that this is not the whole list of herbivores that group. More extensive and detailed examination not only of green space. Kyiv and other cities in Ukraine can expand our knowledge of the fauna-strokatok moles, the most dangerous insect herbivores ornamental species. Thus, in many cities of Europe common, but not in Ukraine is Caloptilia azaleella (Brants, 1913), the Netherlands, the Rhododendron - Parectopa robiniella (Clemens, 1863), Italy, on Robinia - Phyllocnistis citrella (Stainton, 1856), Spain, Citrus - Phyllocnistis vitegenella (Clemens , 1859), Italy, on Vitis - Phyllonorycter leucographella (Zeller, 1850), Italy, on Pyracantha - Phyllonorycter robiniella (Clemens, 1859), Switzerland [25,26,13].

\section{Conclusions}

Established that 54 species of plants that are widely used for landscaping city. Kyiv inhabited by 24 species of moles, strokatok. New to study in Ukraine revealed three types: Phyllonorycter issikii, Phyllonorycter platani and Phyllonorycter emberizaepennella. Calculation of the index occurrence moles feed on plants in the city. Kiev showed that most plants are damaged $\mathrm{C}$. ohridella $(8,54 \%)$ and $\mathrm{P}$. populifoliella $(5,16 \%)$.

A calculation of the index Paly-Kovnatski follows that stands in the city dominants are three types of moles, strokatok (C. ohridella $(94,11 \%)$, P. populifoliella $(86,37 \%)$ and Gracillaria syringella $(59,14 \%)$. established that the rapid spread of mass reproduction and acquired in recent years gracillariidae Cameraria ohridella, Parectopa robiniella and Phyllonorycter issikii. The authors believe that the formation of secondary

Range invasive species strokatok moles-important area of distribution has zhyvytelya plant. Thus, for example, expanding the range of plane Platanus orientalis L. and P. x acerifolia (Ait.) Wild. and contributed to the expansion of the range Phyllonorycter platani (Staudinger). Analysis moles family Gracillariidae, common in the cities of Europe and are kind of lacking in the fauna of cities in Ukraine, which has important theoretical and practical value in protecting plants against particularly dangerous moles, strokatok to study the ecology of insects and protect the ornamental tree and shrub species.

\section{Bibliography}

1. Dmitriev G.V. Fundamentals of protecting green plantations from harmful arthropods / G.V. Dmitriev / K .: Harvest. 1969. - 411 p.

2. Vasilyeva E.A. Minimizing moths of ornamental trees and shrubs of Crimea / E.A. Vasilyeva. Integrated protection of garden and park agrocenosis. Collection of scientific papers. T.111. - Yalta: Gos. Nikitsky Botanical Garden, 1991. - P.84-96.

3. Chumak P.Ya. Ентомологічні екскурсії in the Botanic Garden імені акад. O.V. Fomina / P.Yа. Chumak, V.P. Kovalchuk / Monograph. - Київ: Фітосоціоцентр, 2012. - 72 с.

4. Mikulina IM Invasive insects sappers in the greenery of. Kharkiv // zoological science in modern society: Proceedings of the All-Ukrainian scientific conference devoted to the 175th anniversary of the Department of Zoology - K .: Fitosotsiotsentr, 2009. - S. 307 - 312.

5. Sylchuk O., Chumak PY, Vyhera SN, Kovalchuk V., Lisovyy M. Mill-lagurus lime (Phyllonorycte rissikii Kumata) dangerous invasive pest. Proceedings of International Scientific Conference. Resourcesaving technologies and their legal and economic evaluation in agricultural production (27-28 April 2016), m. Kyiv. - 2016. - P. 76-77.

6. Al Sylchuk Tilia cordata (Tilia cordata Mill.) And its moth-invasive herbivores lagurus (Phyllonorycter issikii Kumata) // Al Sylchuk, PY Chumak, SM Vyhera, VP Kovalchuk, NM Lisovyy, EE Dmitriev // Agroecology magazine. - 2016, № 2 - P. 134-138. 
7. Akimov IA Biology kashtanovoy mynyruyuschey malls - Cameraria ohridella Deschka \& Dimic (Lepidoptera: Gracillariidae) in Ukraine / IA Akimov, MD Zerov, NB Narolskyy, GN Nikitenko, SV Sviridov, A. Lover, MN Babydorych / Vesnyk Zoology. - 2006 - 40 (4). - S. 321 - 332.

8. Trybel S.O. Kashtanova мінуюча міль / C.O. Triebel, OM Gamanova, J. Svjentoslavskih / - K .: Kolobig, 2008. - $72 \mathrm{p}$.

9. Zerov MD Chestnut minuyucha mole / MD Zerov S.V.Svyrydov, NB Narolskyy, ON Lapa / - Kyiv, 2007. $-52 \mathrm{p}$.

10. Koreyka R.V. Gracillariidae - mole-pestrians / / The determinant of insects of the Far East of Russia / R.V. The Koreka. - Vladivostok: Dal'nauka, 1977. - T. 5, part 1. - P. 373-429.

11. Kuznetsov VI The family. Gracillariidae (Lithocolletidae) - moth-doves // Identifier of European insects. H. USSR: in 5 vols. / VI Kuznetsov / Ed. G. Ya. Bei-Bienko. - L .: Science, 1981. - T. IV, part 2. P. 149-311.

12. Kuznetsov V.I. Evolutionary-morphological approach to the taxonomy of moth-pestilence of the genus Phyllonorycter Hbn. (Lepidoptera: Gracillariidae) taking into account the food specialization of species / V.I. Kuznetsov, S.V. Baryshnikova / Entomological Review, 2004.83 (3). - P. 625 - 641.

13. Prins J. Taxonomic history and invasion biology of two Phyllonorycter leaf miners (Lepidoptera: Gracillariidae) with links to taxonomic and molecular datasets / J. Prins, W. Prins, E. Coninck, A.Y. Kawahara, M.A. Milton. \& P.D.N. Hebert /. Zootaxa. 2013. 3709 (4). -P. 341-362.

14. Chernov Yu.l. The main synecological characteristics of soil invertebrates and methods for their analysis // Methods of soil-zoological research. - Moscow: Nauka, 1975. - P. 160 - 216.

15. woody plants Botanical Garden to them. Acad. OV Fomin Taras Shevchenko National University of Kyiv (group of authors). - K .: Fitosotsiotsentr, 2003. - 84 p.

16. dendroflora Ukraine. Wild and cultivated trees and shrubs. Angiosperms. Part I Directory / Kohno M., L. Parkhomenko, Zarubenko AU etc.; Ed. MA. Kohna. - K .: Fitosotsiotsentr, 2002. - 448 p.

17. dendroflora Ukraine. Wild and cultivated trees and shrubs. Angiosperms. Part II. Directory / Kohno M., N. Trofimenko, Parkhomenko LI etc..; Ed. MA. Kohna and NM Trofymenko. - K .: Fitosotsiotsentr, 2005. - $716 \mathrm{p}$.

18. Gorlenko S.V. Pests and diseases of introduced plants / S.V. Gorlenko, N.A. Panko / - Minsk: Science and Technology. - 1987. - $135 \mathrm{p}$.

19. Gorlenko S.V. Stability of wood introducents to biotic factors / S.V. Gorlenko, A.I. Blintsov, N.A. Panko / - Minsk: Science and Technology. - 1988. - 189 p.

20. Rupais A.A. The determinant of pests of ornamental and fruit trees and shrubs on damage $/$ A.A. Rupais. - Riga: Zinatne, 1976. - 324 p.

21. Timofeeva Yu.A. Peculiarities of ecology of lime moth-dolly Phyllonorycter issikii (Lepidoptera: Gracillariidae) in St. Petersburg // Yu.A. Timofeeva // Proceedings of the St. Petersburg Forestry Academy. - 2014. - Issue. 207. - P. 133-141.

22. Selikhovkin AV, Popovichev BG, Musolin DL Pepper moths (Lepidoptera: Gracillariidae) - the most important pests of urban plantings in St. Petersburg / Monitoring and biological methods for controlling pests and pathogens of woody plants: from theory to practice. Materials of the All-Russian Conference with International Participation, Moscow, April 18-22, 2016 Krasnoyarsk: IL SB RAS, 2016. - P. 202-203.

23. Mirzoyan S. A. Dendrophilous insects of forests and parks of Armenia / S. A. Mirzoyan. - Yerevan: Hayastan, 1977. - $452 \mathrm{p}$.

24. Aritunyan RG Biological features of some mining insects in Armenian conditions / R.G. Aritunyan, G.A. Aritunyan, D.I. Manukyan. Materily V V Mizhnorennoi naukovo-konferentsii "Bioriznomanittya ta vratel 'tvarin v ekosistemakh". - Дніпропетровськ: Ліра, 2009. - С. 194-195.

25. Aimbetova S.I. Parasitoid of four invasive species of moth-pestrians (Lepidoptera, Gracillariidae), Bratislava / S.I. Aimbetova, I.V. Ermolaev // Bulletin of the Udmurt University. Biology. The science of the earth. 2016. Vol. 26, no. 1. P. 105-110.

26. Jaworski T. Gracillariidae (Lepidoptera) of the "Skarpa Ursynowska" nature reserve in Warsaw // T. Jaworski //. Entomologi news. 28 (1). -P. 53 - 60. 